Economics Development Analysis Journal 8(3)(2019)

\title{
Space Utilization Change from Residential Into Commercial in Mojosongo, Surakarta
}

\author{
Nadya Astin Saraswati ${ }^{1 凶}$, Ragil Haryanto ${ }^{2}$, Amin Pujiati ${ }^{3}$, Mada Sophianingrum ${ }^{4}$ \\ ${ }^{1,2,4}$ Universitas Diponegoro \\ ${ }^{3}$ Economics Development, Economic Faculty, Universitas Negeri Semarang
}

\begin{tabular}{|c|c|}
\hline \multirow{2}{*}{$\begin{array}{l}\text { Article } \\
\text { Information }\end{array}$} & Abstrak \\
\hline & The area of Mojosongo is a Perumnas which rapidly growing new growth center in Surakarta City. \\
\hline Hisrtory of Article & \\
\hline Received March & $\begin{array}{l}\text { commercial area to facilitate trade activities and services between communities requires (demand) } \\
\text { and people who sell services (supply) that can absorb labor in urban areas so that they can contribute }\end{array}$ \\
\hline $\begin{array}{l}\text { Accepted June } \\
\text { Pusblished August }\end{array}$ & to the Gross Regional Domestic Product (GRDP). The purpose of this study is to find out space \\
\hline Pusonisnea August & $\begin{array}{l}\text { utilization changes from residential into commercial fin Mojosongo in 2004-2019 and to know what } \\
\text { factors influence it. The method used in this study is a quantitative and and the analytical techniques }\end{array}$ \\
\hline $\begin{array}{l}\text { Keywords: } \\
\text { Space Utilization, } \\
\text { Commercial, Residential, } \\
\text { Mojosongo. }\end{array}$ & $\begin{array}{l}\text { used are descriptive analysis techniques, spatial analysis and factor analysis. The subjects of this } \\
\text { study is small-medium enterprises in the area of Mojosongo. The results of this study are } 69 \% \text { space } \\
\text { utilization change from residential into commercial area in Mojosongo which is influenced by } 4 \\
\text { factors: economic factors, the existence of housing, location, and accessibility. }\end{array}$ \\
\hline
\end{tabular}

(C) 2019, Universitas Negeri Semarang

${ }^{\square}$ Corresponding author :

ISSN 2252-6560

Address: : Jl. H. Prof. Soedarto, SH. - Tembalang

Semarang 50275

E-mail: rarasnadya@gmail.com 


\section{INTRODUCTION}

The development of a region is a transformation process that can be determined by the population, community needs, and community activities. In the past few years, big cities have increased rapid growth and their development has become uncontrolled for changes in land intto mixed land use (Shankar \& Vidhya, 2013).

This change will also affect the social and economic. The changes in space utilization are the occurrence of changing particular land into other land use caused by economic development and population dynamics which always increase every year (Weng, 2002). Besides that, the development of a growth area that spread and form spatial patterns (Kumar \& Sangwan, 2013).

The physical development of cities and new growth suburbs in urban areas, it is shown by the growth of retail businesses that are mostly carried out by small-medium enterprises. This development is spread sporadically in areas that are considered as potential locations. One of the driving factors that accelerated this development was the influence of the development of democracy and decentralization in the economic sector that occurred in Indonesia. This spontaneously marked the growth of community business independence in developing their own businesses related to community efforts to survive in a wave of the global economy.
Housing is a basic necessity for urban dwellers with socio-economic characteristics (Almaden \& Cagayan, 2014). Mojosongo is a well-planned public housing and managed by the Spatial Detail Plan (RDTR), which its planning has taken into account and provides a platform for accommodating commercial activities as residential area. But in reality, it has now been predicted that commercial activities in the Mojosongo are increasingly residential changing into mixed function. The change in space utilization that happens in socio-cultural environment of the communities affected by the large number of requests to support daily life it encourages the occurrence of economic growth and growing community become a commercial activity (Serneels \& Lambin, 2001).

Commercial activity is a trading activity that includes the sale or purchase of goods and services to obtain profits by means of trade and all supporting activities (Wicaksono, Sugiyanto, \& Sugiyanto, 2011). Commercial activities according to the type of trade according to (Wardhana, 2016), are divided into trading activities for primary commodities needed daily activities with high expenditure levels. Then, secondary trade such as clothing, household equipment, and tertiary trade such as jewelry, and other luxury trade. Commercial activities in Mojosongo can be seen in the following figure.

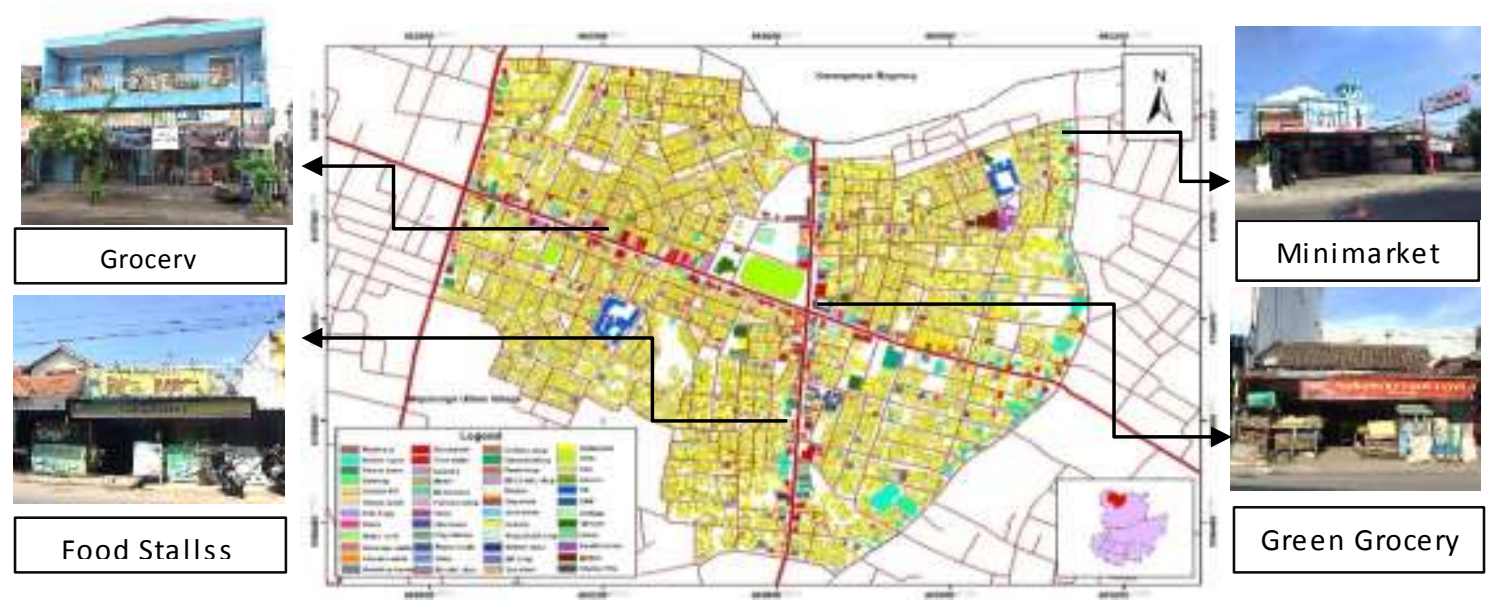

Figure 1. Primary $\bar{C}$ ommodity $\bar{T}$ rading Activities in Area of Mojosongo

Source: Field Observation, 2019 
In the development of commercial activities, it is necessary to know the factors that influenced by economic, environmental, and physical environment (Chapin, 1995). The strategic location and has the potential to improve its economy in the surrounding area (Umar, 2016). This can be a potential and benefit for landowners and employment opportunities make some people use their houses as a place to do commercial (Haryanto, 2016). In addition, the limited land make some people who have houses with a strategic location will use their houses as commercial (Muhajir, 2012). Residential development will also be followed by its main supporting activities, the commercial ones (Putra \& Rahayu, 2015). The development of smallmedium enterprises can be formed a commercial area. Entrepreneurship as a way and process creating and developing economic activities based on innovation creativity. The commercial activity becomes a creative activity and something different or innovative effort to obtain something for himself and add value to the community.

The area of Mojosongo will become increasingly crowded with the emergence of small-medium enterprise, which has implications for commercial functions that were originally intended for housing. In addition, the phenomenon changing of space utilization is influenced by the limited available land affecting the development of other environmental facilities and infrastructure, leading to competition for strategic locations along with the increasing land price (Nidyasari, 2011). The development of commercial activities in Mojosongo needs to be investigated. So, it can be seen how to change space utilization in the area of Mojosongo from 2004-2019. This research was also conducted to see how the development of commercial activities in the Mojosongo and the effect of changing space utilization will have implications for the development of the economic sector.

\section{RESEARCH METHODS}

A study that examines commercial activities for the changes of sattlement space utilization in the area of Mojosongo, Surakarta using quantitative study methods based on numerical data or numerically processed by statistical methods as a concrete or empirical method, objective, measurable, rational and systematic data (Sugiyono, 2012). While quantitative descriptive analysis will be shown in the form of tables, diagrams and brief descriptions. The analysis that will be used in this study includes analysis of commercial activities in the area of Mojosongo to determine the development of commercial activities. In this analysis are provided to reveal the patterns of

$$
\text { Slovin's Formula: } \quad \mathrm{n}=\frac{N}{1+N(d) 2}
$$

commercial activities that can be commercialized. Furthermore, there is an analysis of commercial activities within settlement space in Mojosongo, which is based on the meaning of the overview to commercial activities form and characteristics, whether or not there is a difference in each area. There is an analysis of space utilization changes from residential into commercial to find out how the change is in the building, the function, and the physical condition of the commercial buildings. Lastly, this study aimed at factors that influence commercial development to study the factors that influence commercial in Mojosongo. Study data was obtained from questionnaires, interviews, and observations as the basis of information related to emerging commercial activities. While for sampling techiniques, studyers use purposive technique sampling and area technique sampling and Slovin formula (Sevilla, 2007). The sampling method with a total population of 618 commercial, the amount was obtained after conducting a field survey. Subjects in this study are commercial business actors located in Mojosongo, Surakarta.

After using the Slovin formula, it has been revealed that this study shall involve around 86 commercial actors with $10 \%$ margin of error so that the level of trust is $90 \%$.

$$
n=\frac{618}{(618)(0,1)^{2}+1}=86 \text { sample }
$$

The number of samples obtained based on Slovin formula, with the confidence level used to 
determine the response of $90 \%$ and the complaint limit of $10 \%$ with a total amount of 618 commercial obtained a sample size of 86 . The sampling technique that will be used in the sample taken is purposive sampling the one who lent the respondent who was the source of the data was clearly a commercial activity in the area of Mojosongo and did not collect data from noncommercial activities.

\section{RESULTS AND DISCUSSION}

Based on the plan carried out by the government as contained in the Spatial Detail Plan (RDTR) document in Surakarta City, the area of Mojosongo is mostly planned as a residential area, only a few parts located along in the Mojosongo are planned as commercial. As time goes by development area of the residential has an impact of the area in Mojosongo.

Thus impact very rapid commercial development due to the commercial purpose of fulfilling the needs. The development of Mojosongo currently uses the space that is already not in accordance with what should be planned. The area of Mojosongo began to be dominated by many existing commercial activities. Commercial activities also develop until entering residential areas not only along the corridor.

The results of this study are in accordance with the theory of (Hartshorn, 1992) where this pattern of specialized areas having commercial activities. There are developed in housing grew and spread and were not planned to meet daily needs such as food stalls, food stalls, laundry, and the activities grows sporadically with certain primary commodities. The commercial developments that took place in the residential area of Mojosongo from 2004 to 2019 emerged due to the same linkages to meet the demands of the daily needs of people in residential areas.

Whereas in the main corridor of the area of Mojosongo there is a pattern of development of ribbons where according to theory of (Hartshorn, 1992) as the criteria for the development of these commercial activities are spread along the side of the highway corridor.
Commercial activities with the pattern of ribbons can occur in a planned or not so that the growth of the business usually depends on the flow of traffic contained in the road corridor that is adjusted to the needs of consumers in meeting the needs of goods or services. So that, these characteristics will affect the pattern of development of commercial activities in the form of ribbons where along the main corridor to develops the needs of residents inside and outside the area of Mojosongo.

The characteristics of commercial activities in the area of Mojosongo is divided into 4 zones based on a predetermined zone grouping. This aims to find out in more detail the differences in the characteristics of commercial activities in the region. In zone A there are wider residential areas compared to other zones and have a greater number of residential buildings than other zones, it has $37 \%$ of the total existing residential buildings is 1,549 housing units. In zone B it is surrounded by the main corridor of the Mojosongo, namely Jaya Wijaya Road and Tangkuban Perahu Road are directly in contact with the Surakarta City Ring Road.

Whereas zone $\mathrm{C}$ has the characteristics of having complete public facilities which are the center of supporting activities in the Mojosongo such as traditional markets namely Sibela Market, hospital, and street vendor shelter. Besides that, in zone $\mathrm{D}$ it has recreational facilities in the form of a city-scale park, namely Jaya Wijaya Park and a multi-purpose building of Nahdatul Ulama University that are used to be used for certain events from universities.

The differences in the characteristics of commercial activities spread in the Mojosongo area can be classified based on trade commodities according to (Gallion \& Eisner, 1983) and services according to Law No. 7 of 2014 concerning Trade. in this study it was found that commercial activities in the Mojosongo area were compatible with the classification determined according to (Gallion, 1983). The following are the results of the analysis of the characteristics of zones A, B, C, and D can be seen in the table as follows. 
Table 1. The Results of Characteristics Analysis of Commercial Activities in the Area of Mojosongo Based on Grouping 4 Zones

\begin{tabular}{|c|c|c|c|}
\hline No & Zone & Characteristic Commercial Activities & Space utilization \\
\hline 1 & Zone $\mathrm{A}$ & $\begin{array}{l}\text { Commercial activities that dominate in zone } \mathrm{A} \text { in the area } \\
\text { of Mojosongo are the types of primary commodities and } \\
\text { housing services. The dominant ownership of commercial } \\
\text { activities is mostly private property with a dominant } \\
\text { operational time of } 12-18 \text { hours per day. Existing } \\
\text { commercial activities on average have been operating for } \\
15 \text { years. In addition, most of the reasons for establishing } \\
\text { a business along with the choice of location are based on } \\
\text { the existence of a residential area around as a livelihood. }\end{array}$ & $\begin{array}{l}\text { Most commercial } \\
\text { buildings in zone } \\
\text { A are dominated } \\
\text { by mixed } \\
\text { functions, } \\
\text { namely house } \\
\text { and commercial. }\end{array}$ \\
\hline 2 & Zone B & $\begin{array}{l}\text { Commercial activities that dominate in zone B in the area } \\
\text { of Mojosongo are commercial types of housing services } \\
\text { and so are primary commodities and transportation } \\
\text { service. The dominant ownership of commercial activities } \\
\text { are use business premises. Whereas the operational time in } \\
\text { this zone ranges from } 12-18 \text { hours per day. Commercial } \\
\text { activities have been operating between } 1-6 \text { years ago. In } \\
\text { addition, most of the reasons for establishing a business } \\
\text { along with the selection of locations are also based on } \\
\text { strategic location and close to the main road. }\end{array}$ & $\begin{array}{l}\text { Most commercial } \\
\text { buildings in zone } \\
\mathrm{B} \text { are used as } \\
\text { business } \\
\text { premises. }\end{array}$ \\
\hline 3 & Zone C & $\begin{array}{l}\text { Commercial activities that dominate in zone } C \text { in the area } \\
\text { of Mojosongo are commercial types of housing services } \\
\text { and so are primary commodities and transportation } \\
\text { service. The dominant ownership of commercial activities } \\
\text { are use business premises. Whereas the operational time in } \\
\text { this zone ranges from } 12-18 \text { hours per day. Commercial } \\
\text { activities have been operating between } 6-10 \text { years ago. In } \\
\text { addition, most of the reasons for establishing a business } \\
\text { along with the selection of locations are also based on } \\
\text { strategic location and close to the main road. }\end{array}$ & $\begin{array}{l}\text { Most commercial } \\
\text { buildings in zone } \\
\mathrm{B} \text { are used as } \\
\text { business } \\
\text { premises. }\end{array}$ \\
\hline 4 & Zone D & $\begin{array}{l}\text { Commercial activities that dominate in zone } \mathrm{D} \text { in the area } \\
\text { of Mojosongo are the types of primary commodities and } \\
\text { housing services. The dominant ownership of commercial } \\
\text { activities is mostly private property with a dominant } \\
\text { operational time of } 12-18 \text { hours per day. Existing } \\
\text { commercial on average have been operating for } 10-15 \\
\text { years. In addition, most of the reasons for establishing a } \\
\text { business along with the choice of location are based on the } \\
\text { existence of a residential area around as a livelihood. }\end{array}$ & $\begin{array}{l}\text { Most commercial } \\
\text { buildings in zone } \\
\text { A are dominated } \\
\text { by mixed } \\
\text { functions, } \\
\text { namely house } \\
\text { and commercial. }\end{array}$ \\
\hline
\end{tabular}

Source: Study Analysis, 2019

By analyzing changing space utilization into commercial space, it can be seen to extent commercial developments spread and how many commercial activities with mixed functions by looking at the use of residential space in terms of functions and physical conditions of buildings.
As well as commercial activities that develop in the Mojosongo area are divided into 2 characters, namely there are those that are used as a place of commercial and some are mixed functions (residential and commercial) which are scattered within the residential area as well as in the main 
corridor Mojosongo. The proportion of building functions found in area of Mojosongo can be seen in the graph as follows.

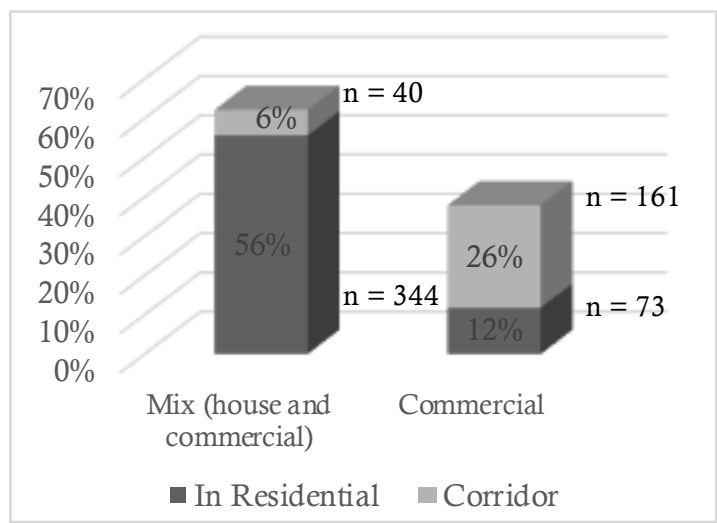

Figure 3 Graphical Percentage of the Commercial Building Function in Mojosongo Source: Study Analysis, 2019

Based on the above graph it can be seen that commercial activities seen from the function of the building are mostly dominated by mixed functions. The percentage of the function of this mixed building is $56 \%$ or there are 344 commercial buildings from all commercial activities in the Mojosongo area inside the housing. Whereas in the main corridor Mojosongo, commercial activities dominate with only $26 \%$ of the function as a commercial or 161 commercial buildings. The results of this study are reinforced by the results of study conducted by (Hermaputri, 2013) where most houseowners rent or make their own houses to become commercial. On the other hand, people rarely rent out all their residential buildings. This is because the initial purpose of commercial owners who are in the Mojosongo area to buy lots in Perumnas as housing. Then after seeing the commercial building functionality, it is also necessary to understand the physical condition. During the last 15 years the change in space utilization that occurred in the area of Mojosongo was quite significant compared to the unchanging space. Next, there is a large percentage change in residential space utilization into commercial activities in the area of Mojosongo in 2004-2019. Here is the following graph.

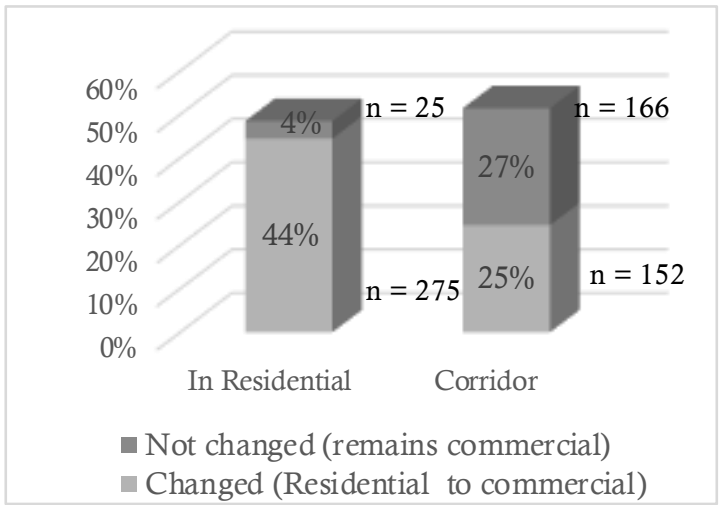

Figure 4. Percentage Changes in Residential Space Utilization Graphs into Commercial in Mojosongo 2004 - 2019

Source: Study Analysis, 2019

Based on the graph above, it can be seen that in the last 15 years, the Mojosongo area has undergone a change in the use of residential space to be commercially occurring in the housing as well as in the main corridor of the region. A total of $69 \%$ or equivalent to 427 houses experienced changes in spatial use with the details $44 \%$ were in housing and $25 \%$ were in the main corridor. The results of this study are reinforced by the results of study conducted by (Puteri, 2018) is the types of commercial activities that have undergone changes mostly in housing are dominated by primary commodities of a residential area in Mojosongo that provide daily necessities such as food stalls, restaurants, vegetable and fruit shops, and so on. While changes in commercial activities in the main corridor are dominated by secondary and tertiary commodities, as well as services such as clothing, bags, stationery shops, workshops, and so on. This proves that in this region the changes that occur are quite dominant compared to the unchanged data which shows a figure of $31 \%$ or equivalent to 191 houses.

Commercial activities that have not undergone this change are in the form of shophouses or shops where in 2004 they had become places of business and this unchanged situation occurred in vacant land which was used as a place of business. The map of changes in housing use has become a commercial activity in the Mojosongo area in 2004 until 2019 can be seen in the picture below. 


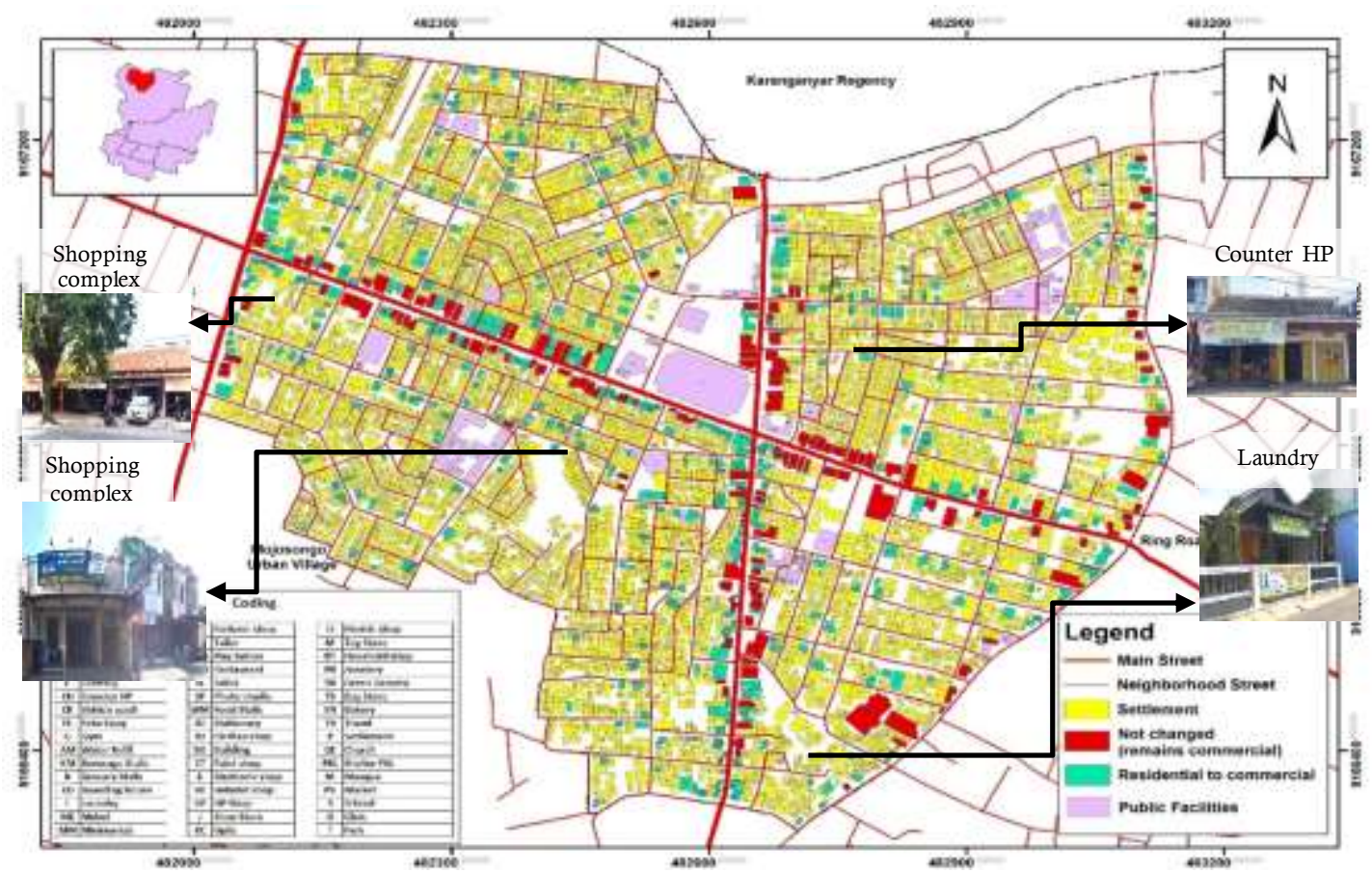

Figure 5. Map of Changes in the Use of Residential spaces to be Commercial in the Area of Mojosongo 2004-2019

Source: BAPPEDA Surakarta City, 2018 and Google Earth, 2018 (with reprocessing)

Based on the map of change above, it can be seen how many functions of the building have undergone changes and that have not changed. Space utilization changin in the area of Mojosongo occur a lot into the settlements compared to the road corridors. In the last 15 years, the area of Mojosongo has undergone a change in the use of residential space to become commercial as much as $69 \%$. This proves that in this region the changes that occur are quite dominant compared to the unchanged data showing a figure of $31 \%$. Changes that occur are characterized by mixed and commercial functions. In addition, the changes that occur most of the existing commercial activities go without the official business permit or IMB. The IMB that is still in effect is with a residential function or even none. The first analysis used uses descriptive statistics to see how the effects of each variable affect. After that, using factor analysis to find out which variables are formed and correlate with each other into one factor of variation of existing data. To see the effect of each variable has been determined using descriptive analysis and can be seen in table 2 . Looking at the table above, the average score or mean of the influencing variables, it can be classified into three groups. This grouping is done by grouping variables that have an average value of almost the same into one with the assumption that the influence of these variables on space utilization change from residential into commercial area in Mojosongo is the same. The results of this study are consistent with the study conducted by (Hermaputri, 2013) about the level of influence of factors that affect changes in the utilization of residential space where the most influential groups are the existence of housing, strategic location, consumption patterns, and infrastructure support because in zone $\mathrm{A}$ and Zone D. 
Table 2. Average Value of Each Variable Score

\begin{tabular}{|c|c|c|c|}
\hline Variabel & Mean & $\begin{array}{l}\text { Level of } \\
\text { Influence }\end{array}$ & Note \\
\hline $\begin{array}{l}\text { Residential } \\
\text { Existence }\end{array}$ & 4,74 & Influential & $\begin{array}{l}\text { This variable has the highest influence because the } \\
\text { existence of residential triggers the development of } \\
\text { commercial activities }\end{array}$ \\
\hline $\begin{array}{l}\text { Strategisc } \\
\text { Location }\end{array}$ & 4,60 & Influential & $\begin{array}{l}\text { Has a high influence because the strategic location of } \\
\text { business factors becomes an opportunity for the } \\
\text { community to open a business }\end{array}$ \\
\hline $\begin{array}{l}\text { Consumption } \\
\text { Level }\end{array}$ & 4,37 & Influential & $\begin{array}{l}\text { Has a high influence because the community's } \\
\text { consumption level affects the development of } \\
\text { commercial activities }\end{array}$ \\
\hline $\begin{array}{l}\text { Infrastructure } \\
\text { Support }\end{array}$ & 4,00 & Influential & $\begin{array}{l}\text { Has a high influence because most of the existing } \\
\text { commercial requires good facilities and infrastructure } \\
\text { services }\end{array}$ \\
\hline $\begin{array}{l}\text { Location } \\
\text { Security }\end{array}$ & 3,79 & $\begin{array}{l}\text { Quite } \\
\text { Influential }\end{array}$ & $\begin{array}{l}\text { It's quite influential because most of the commercial } \\
\text { needs security in every effort }\end{array}$ \\
\hline Land Rent & 3,77 & $\begin{array}{l}\text { Quite } \\
\text { Influential }\end{array}$ & $\begin{array}{l}\text { It's quite influential because the price of rental space } \\
\text { determines someone in opening a business }\end{array}$ \\
\hline Land Price & 3,72 & $\begin{array}{l}\text { Quite } \\
\text { Influential }\end{array}$ & $\begin{array}{l}\text { It's quite influential because the price of land space } \\
\text { determines someone in opening a business }\end{array}$ \\
\hline $\begin{array}{l}\text { Traffic } \\
\text { Condition }\end{array}$ & 3,21 & $\begin{array}{l}\text { Quite } \\
\text { Influential }\end{array}$ & $\begin{array}{l}\text { It's quite influential because on the Jaya Wijaya park } \\
\text { and Tangkuban Perahu roads of the Mojosongo area } \\
\text { is a crowded main corridor }\end{array}$ \\
\hline $\begin{array}{l}\text { Ease } \\
\text { Reaching } \\
\text { Location }\end{array}$ & 3,08 & $\begin{array}{l}\text { Quite } \\
\text { Influential }\end{array}$ & $\begin{array}{l}\text { It's quite influential because the people of the } \\
\text { Mojosongo area will be facilitated in reaching } \\
\text { business places }\end{array}$ \\
\hline $\begin{array}{l}\text { Government } \\
\text { policy }\end{array}$ & 2,58 & $\begin{array}{l}\text { Less } \\
\text { Influential }\end{array}$ & $\begin{array}{l}\text { Less influence because the people of the Mojosongo } \\
\text { Region did not pay much attention to it }\end{array}$ \\
\hline $\begin{array}{l}\text { Simillar } \\
\text { Business }\end{array}$ & 2,23 & $\begin{array}{l}\text { Less } \\
\text { Influential }\end{array}$ & $\begin{array}{l}\text { Less influence because if too many similar businesses } \\
\text { will increase business competition }\end{array}$ \\
\hline
\end{tabular}

Source: Study Analysis, 2019

The variable existence of housing has a high influence on commercial development, because in residential areas it requires the fulfillment of daily needs as a support for residential activities in the form of commercial. Besides that the high pattern of public consumption in the housing area has affected commercial emergence which has led to changes in the use of space from residential to commercial. The existence of infrastructure support also affects the changes that occur where complete infrastructure facilities around the commercial become a distinct advantage in opening a commercial activities. In zone $\mathrm{D}$ this has a recreational facility with a city scale, namely Jaya Wijaya park which is an attraction for opening businesses around these facilities. Besides that, the strategic location influences the change in the use of residential space to be commercial in zones B and C. This is because these two zones intersect directly with the Ring Road and are surrounded by the main corridor, so the strategic location becomes an opportunity to open a business.

The results of the analysis obtained from the 11 variables formed 4 factors that influence changes in spatial utilization in the area of Mojosongo, it can be seen in table 3 below: 
Table 3. The Names of Factor Formed

\begin{tabular}{|c|c|c|c|c|c|}
\hline \multirow[b]{2}{*}{ Variable } & \multicolumn{4}{|l|}{ Factor } & \multirow[t]{2}{*}{ Name of Factor } \\
\hline & Faktor 1 & Faktor 2 & Faktor 3 & Faktor 14 & \\
\hline VKP_1 & .321 & .087 & .048 & .832 & \multirow{4}{*}{$\begin{array}{l}\text { Influence of Residential } \\
\text { Factor }\end{array}$} \\
\hline VKP_2 & -.422 & .426 & -.097 & -.530 & \\
\hline VKP_3 & -.277 & -.024 & .263 & .559 & \\
\hline VLo_1 & .183 & .610 & .174 & .498 & \\
\hline VLo_2 & -.052 & .752 & .277 & -.363 & \multirow{3}{*}{ Location Factor } \\
\hline VLo_3 & .025 & .865 & -.091 & -.040 & \\
\hline VLo_4 & .197 & .675 & .174 & .076 & \\
\hline VA_1 & .278 & .264 & .415 & -.068 & \multirow[t]{2}{*}{ Accessibility Factor } \\
\hline VA_2 & -.233 & .075 & .744 & .048 & \\
\hline VE_1 & .865 & .157 & .112 & -.165 & \multirow{2}{*}{ Economic Factor } \\
\hline VE_2 & .885 & .136 & .009 & .032 & \\
\hline
\end{tabular}

Source: Study Analysis, 2019

Based on the results of factor analysis, it can be seen that the factors that influence space utilization changes from residential into commercial activities in the area of Mojosongo consist of 4 variables. Each parameter that forms the variable has a shape greater than 0.5 , which indicates that each of these parameters is feasible to form a variable. There are 4 variables that are formed, namely the influence factor of residential (housing existence, consumption level, government policy), location factors (strategic location variables, location security variables, facilities and infrastructure support and similar business) accessibility factors (ease of reaching location variables and traffic condition variables, economic factors (land prices and land rent).

The existence of a residential area will affect the land price and land rent of the surrounding land.This is due to the high demand for fulfilling community needs such as household needs and in supporting other needs. Thus resulting in land the area of Mojosongo used for commercial activities. Therefore, the development of commercial activities affects the increase land rent in Mojosongo and surrounding areas, especially land that has a strategic location as well as the high land price in Mojosongo, affecting for commercial

Based on factor economi in the variable land prices and land rent it can be interpreted that the respondents have a perception of the increasingly affordable land prices in area of Mojosong. More people will buy land to invest around the area. Land rent in the area of Mojosongo are between 15 million and 60 million per year. Although the average respondent stated that the rental price is not cheap, business operators in the Mojosongo area are still able to reach the rental price. This makes the changes in spatial use quite significant and spread in the area of Mojosongo. Therefore, along the corridor and inside the Mojosongo area, land price will continue to rise every year so that there will be many changes in the function of the building because the land owner will sell or rent out the place of business to take advantage of the opportunities.

\section{CONCLUSION}

The area of Mojosongo is an area that is included in the Mojongo Village, District of Jebres. Based on Regional Regulation No. 1 of 2012 concerning the Regional Spatial Plan for 2011-2031, the area of Mojosongo in Mojosongo Village is included in BWK IV where its main function is explained in the Surakarta City Spatial Detail Plan (RDTR), namely as a residential area. While the Mojosongo area itself is a residential area, where over time the area has experienced development due to commercial activities to support housing activities. Previously, the Housing Ministry certainly 
predicted the emergence of commercial activities by providing a container to accommodate these commercial activities. However, in reality the existing commercial activities cannot be accommodated in containers that have been provided previously so that commercial activities in the area of Mojosongo is increasingly developing into residential areas. Therefore, there is a phenomenon of changes in space utilization where the original function as a residence turned into commercial activity or mixed function.

The study can be concluded that the area of Mojosongo has undergone space utilization change from residential into commercial in $74 \%$ or equivalent to 457 houses experiencing changes in space utilization with a total of $47 \%$ in housing main. Whereas $26 \%$ or equivalent to 161 houses of commercial activities did not experience this change in the form of shophouses or shops where in 2004 it had become a place of business and this unchanged situation occurred in vacant land which was used as a commercial. The commercial activities that change the most residential areas to be commercial in the Mojosongo is primary commodities. The changes that occur are characterized by mixed functions in one building namely residential and commercial as well as changing the function of the house into a commercial.

Whereas based on the grouping of factors that influence space utilization from residential into commercial by looking at the level of influence on changes in spatial into 4 factors are formed, namely the influence factor of the housing area (housing existence, consumption patterns and government policies), location factors (strategic location, location security, support for facilities and similar businesses), accessibility factors (ease of reaching locations and conditions traffic, economic factors (land prices and rental prices).

\section{REFERENCES}

Almaden, C. R. C., \& Cagayan, X. U. De. (2014). Housing Affordability Challenges : the Case of the Median Income Households in Cagayande Oro City Philippines. College of Arts and Sciences, 4(10), 95-107.
Gallion, A., Eisner, S. (1983). The Urban Pattern: City Planning and Design, D Van.

Haryanto, R., Soetomo, S., \& Buchori, I. (2016). A Phenomenon of Spatial Economic Democracy: Emerging Small-Medium Enterprises along the Street Corridors of Yogyakarta, Indonesia. Journal of Settlements and Spatial Planning, 7(2), 137.

Hermaputri, R. L., \& Haryanto, R. (2013). "Analysis of Factors Affecting the Development of Commercial Activities in the D.I Road Corridor. Pandjaitan Kota Samarinda". PWK Technical Journal, 2 (3), 338-348.

Kaiser, E. J., Godschalk, D. R., \& Chapin, F. S. (1995). Urban land use planning (Vol. 4). University of Illinois Press Urbana, IL.

Kumar, S., \& Sangwan, R. S. (2013). Urban Growth, Land Use Changes and Its Impact on Cityscape in Sonipat City Using Remote Sensing and GIS Techniques. Haryana , 2(1), 326-332.

Muhajir, M. A. (2012). "Spatial Patterns of Change in Building Functions on the Main Road of Depok City, West Java". University of Indonesia.

Nidyasari. (2011). Changes in Occupational Functions and Territorial Conflict of Depok Architecture Study Program. University of Indonesia.

Pontoh, N. K., \& Kustiwan, I. (2009). Introduction to Urban Planning. ITB Publisher: Bandung.

Purwanto, A. N., Ernawati, J., \& Wijaksono, A. D. (2017). The Factors of Land use Conversion from Settlement Area to Commercial Area at IR . Soekarno / Merr Street, Rungkut Street, and Medokan Ayu Street, Surabaya. Indikator, (4), 86-93.

Puteri, R. D. A., \& Haryanto, R. (2018). Land-Use Shifting from Residential into Commercial Activities in the Region of Tlogosari Kulon, Semarang. International Journal of Scientific and Study Publications, 8(7), 183-194.

Putra, B. Z., \& Rahayu, S. (2015). Factors Affecting Housing Selection and House Types in Emerald Hill Housing. PWK Engineering (Urban Area Planning), 4(4), 681-691.

Serneels, S., \& Lambin, E. F. (2001). Proximate causes of land-use change in Narok District, Kenya : a spatial statistical model, $85,65-81$.

Sevilla, C. G. et. al. (2007). No Title. Study Methods. Rex Printing Company. Quezon City.

Shankar, B., \& Vidhya, D. (2013). Changing Dynamics of Land Use in Residential 
Neighbourhood of Vani Vilasa Mohalla, Mysore. 3(2), 678-684.

Sugiyono. (2012). Metode Penelitian Kuantitatif, Kualitatif, dan R\&D. Bandung:CV Alfabeta.

Umar, F. P., Sela, R. L. E., \& Tarore, R. C. (2016). Changes in the Function of Space Utilization in Mogolaing Village, Kotamobagu City. Spatial Journal. 3 (3), 156-163.

Wardhana, I. W., \& Haryanto, R. (2016). Study of the Utilization of Commercial Activities in the Corridor of Taman Siswa Street in Semarang City. City Development Journal, 4 (1), 49.

Weng, Q. (2002). Land use change analysis in the Zhujiang Delta of China using satellite remote sensing, GIS and stochastic modelling. 273284.

Wicaksono, T., Sugiyanto, F. X., \& Sugiyanto, F. X. (2011). Analysis of Factors Affecting Changes in the Use of Housing for Commercial Purposes in the Tlogosari Kulon Area, Semarang. Diponegoro University. 